\title{
The Genitive-Accusative of the Personal Pronouns in Old Church Slavonic
}

\author{
Michael Weiss* \\ Department of Linguistics Cornell University, Ithaca, NY, USA \\ mlweiss36@gmail.com
}

\begin{abstract}
In those Slavic languages that retain both a case system and clitic pronominal forms two case-related phenomena partially overlap: (1) Masculine animate nouns and gendered pronouns display differential object marking with sensitivity to the animacy hierarchy. Some subset of these forms with the highest score on the animacy hierarchy show the original genitive form instead of the expected accusative in contexts that otherwise call for that case, the so-called genitive-accusative. (2) Personal pronouns also show instances of the genitive for the accusative but with important differences. In languages with a clitic stressed contrast for oblique pronominals the accusative forms generally are continued as clitics and the genitive forms as stressed. It is unlikely that the nominal and personal-pronominal gen.-acc. are unrelated. On the other hand, the case choice for nouns and gendered pronouns is sensitive to the animacy hierarchy, but for the personal pronouns the choice between genitive and accusative is phono-semantic. Whatever semantic structure evokes the stressed forms leads to the production of the gen.-acc. I suggest that gen.-acc. began with $o$-stem masculine personal names, the most prototypical expression of the semantic class [+human, +male, + free, +definite] and was extended to the interrogative pronoun (gen.-acc. kogo). The interrogative pronoun had just those properties that allowed the remapping of an animacy hierarchy into a tonicity distinction.
\end{abstract}

* Thanks to E. Wayles Browne, Miloje Despić, Andrew Garrett, Alexis Manaster Ramer, Krassimira Trifonova, Brent Vine, Olga Yokoyama, Draga Zec, and two anonymous reviewers for help and advice.

(C) MICHAEL WEISS, 2015 | DOI: 10.1163/22125892-00301005

This is an open access article distributed under the terms of the Creative Commons

Attribution-Noncommercial 3.o Unported (CC-BY-NC 3.0) License. 


\section{Keywords}

Slavic - Old Church Slavonic - pronominal clitics - genitive-accusative

\section{$1 \quad$ Introduction}

In those Slavic languages that retain both a case system and clitic pronominal forms we find two case-related phenomena that seem partially to overlap. ${ }^{1}$ Masculine animates and gendered pronouns display differential object marking (DOM; see Bossong 1984; Mardale 2008) with sensitivity to the animacy hierarchy (Silverstein 1976; Aissen 2003). Some subset of these forms with the highest score on the animacy hierarchy show the original genitive form instead of the expected accusative in contexts that otherwise call for that case.

(1) OPol. 14th cent.

Czysta, Krysta jeś poczęta ${ }^{2}$

pure.NOM.SG.F Christ.GEN-ACC AUX.2s conceived.NOM.SG.F

'Pure, you conceived Christ.'

The various Slavic languages have extended the animate gen.-acc. to different degrees on various axes (semantic, morphological). ${ }^{3}$

\section{2 \\ The Genitive-Accusative of Personal Pronouns}

Personal pronouns also show instances of the genitive for the accusative but with important differences. In languages with a clitic $\sim$ stressed contrast for oblique forms of the personal pronoun the accusative forms generally are continued as the clitic forms and the genitive forms are the stressed ones.

(2) SCr. 1st SG. stressed ACC. mène, clit. me, 2nd SG. stressed ACc. tèbe, clit. te

1 Abbreviations: $\mathrm{M}=$ Codex Marianus, $\mathrm{z}=$ Codex Zographensis, $\mathrm{A}=$ Codex Assemanianus, $\mathrm{S}=$ Savvina Kniga, $\mathrm{V}=$ Vatican Palimpsest, $\mathrm{C}=$ Codex Clozianus, $\mathrm{K}=$ Kiev Missal, $\mathrm{O}=$ Ostromir Gospel, Supr. $=$ Codex Suprasliensis, Ps. Sin. $=$ Psalterium Sinaiticum, Euch. Sin. $=$ Euchologium Sinaiticum, PSN = Psalterium Sinaiticum Novum.

3 See Huntley 1980, Klenin 2009 for a survey. 
Pol. 1st SG. stressed ACc. mnie, clitic mię 2nd SG. stressed Acc. ciebie, clitic cie

For these two languages the old plural accusatives ny and $v y$ have been entirely ousted by the old genitives.

(3) SCr. 1st PL. stressed ACC. nâs, clit. nas

2nd PL. stressed ACC. vâs, clit. vas

Pol. 1st PL. nas

2nd PL. was

For Russian the old accusatives have been entirely lost in the standard language, but on clearly passed through the stage still preserved in South and West Slavic (gen.-acc. menjá is mene gen. x mja acc. < $\left.{ }^{*} m e ̨\right){ }^{4}$

\section{3}

\section{Similarity, Differences, and Questions}

Similarity: The use of the genitive in syntactic contexts otherwise requiring the accusative is rarely found outside of Slavic. ${ }^{5}$ Even Baltic, which shares the innovative genitive after negative verbs, does not show the Slavic phenomenon. ${ }^{6}$ It is unlikely that the nominal and personal-pronominal gen.-acc. are unrelated.

Differences: The case choice for nouns and gendered pronouns is sensitive to the animacy hierarchy. The animacy hierarchy is irrelevant for the personal pronouns, which predominantly have human reference, and almost always have animate reference. In the personal pronouns the choice between genitive and accusative is phono-semantic. Whatever semantic/pragmatic structure evokes the stressed forms indirectly leads to the production of the gen-acc. This is obviously not a factor for nominals. The personal pronouns have (or had) the contrast in the singular and plural, as is shown by the total replacement of the old acc. forms ny and $v y$ with the exception of Bulgarian which has $n i, v i$

4 V. Kiparsky 1967:137 cites Иду на вы "I come against you," an ов declaration of war from the Tale of Bygone Years. See Zaliznjak 2008:36-37.

5 One of the reviewers notes that Ossetic and Mordvin also have Dom with the genitive for definite objects. But given the geographic distribution of these it seems plausible that these similarities result from contact. See Nichols 1993:387.

6 Baltic Fennic also uses the partitive after negated verbs, but has no trace of the gen.-acc. 
as the enclitic dat./acc. contrasting with accented nas, vas. ${ }^{7}$ But nominal and gendered pronominal forms originally only made this contrast in the singular. Masculine animate nouns take the ending $-a$ in all Slavic languages that retain case. And even in Bulgarian and Macedonian there are traces of $-a$ in both the standard languages and in the dialects. ${ }^{8}$ Serbo-Croatian and Slovene preserve the original situation.

Questions: What is the original distribution of the gen.-acc. vs. acc. pronominal forms in ocs and Novgorodian and what can be reconstructed for PS? What is the connection between nominal and pronominal gen.-acc.? Where does the innovation originate and how did the reinterpretation happen?

\title{
4 The Slavic Personal and Reflexive Pronoun
}

\author{
Oldest Old Church Slavonic ${ }^{9}$
}

$\begin{array}{llllllllll}\text { 1 sg. } & \text { 1 sg. } & \text { 2 sg. } & \text { 2 sg. } & \text { refl. } & \text { refl. } & \text { 1 pl. } & \text { 1 pl. } & \text { 2 pl. } & \text { 2 pl. } \\ \text { Str. } & \text { C } & \text { Str. } & \text { C } & \text { Str. } & \text { C } & \text { Str. } & \text { C } & \text { Str. } & \text { C }\end{array}$

\begin{tabular}{|c|c|c|c|c|c|c|c|c|c|c|}
\hline acc. & $m e$ & $m e \underline{e}$ & $t e$ & $t e$ & $s e$ & $s e$ & ny & ny & vy & vy \\
\hline dat. & mŭně & $m i$ & tebě & $t i$ & sebě & $s i$ & namŭ & & vamŭ & \\
\hline
\end{tabular}

Str. $=$ Stressed, $\mathrm{C}=$ Clitic $^{10}$

$7 \quad$ Macedonian has dat. nam ni, vam vi and acc. nas ne, vas ve with the accusative forms created on the model of the acc. sg. clitic me and te.

8 One of the referees calls my attention to the definite object form of Bulgarian света 'world' which continues the old gen.-acc.

9 By Oldest Old Church Slavonic I mean the manuscripts datable to the 1oth and early nth centuries (the Moravian recension (the Kiev Missal) and the Ohrid school Glagolitic manuscripts). The representation in the table above is somewhat idealized. See the table in section 5 for actual figures.

10 The claim is sometimes made that Old Polish, Kashubian, and Polabian retained a reflex of the originally expected clitic form * $m e{ }^{*} t e$, * $s e$ (Weiss 2011:326; the originator of the claim seems to have been Berneker 1904). Some OPol. (e.g. the Psatterz floriański) has gen.-acc. mie, cie, sie as clitic objects distinct from na mię, cię, się. Kashubian has mie, ce, se but after prepositions na mia ca, sa, and Polabian had -me, -te, -se but no mang, tang, sang. Most probably, however, these forms are analogical to the ending of the tonic gen.-acc. mnie, etc. after preposition mię was retained. See Vaillant 1958:34. 
In the case of the dat. sg. it is clear from the two forms and the distribution of the shorter forms that there was an stressed $\sim$ enclitic opposition. These clitic forms continue PIE clitic forms. Cf. Ved. $m e$, $t e$, etc. The accusative forms ${ }^{11}$ given normally pattern as clitics, but they can occur in positions where true clitics would be excluded, e.g. clause-initial position.

(4) M. $10.40\left(\mathrm{M}, \mathrm{Z}, \mathrm{A}, \mathrm{O}^{12}\right)$ :

iže vy priemletŭ, ${ }^{13}$ me ${ }^{2}$ priemletŭ

rel.NOM.SG you.ACC.PL receives.3.SG me.ACC.SG receives.3.PL

ho dekhómenos humâs, emè dékhetai

'He that receiveth you receiveth me.'14

Note too that a clitic would be surprising for a realization of a strongly contrastive pronoun.

(5) Ps. Sin. $40.13(41.12)$ :

mje že za nezŭ[lo]bq mojq priętŭ

me.ACC.SG PTC for integrity.ACC.SG my.ACC.SG uphold.2.SG

emoû dè dià tèn akakían antelábou

'And as for me, thou upholdest me in mine integrity.'

(6) Euch. Sin. 8a6:

te molimŭ

you.ACC.SG pray.1.PL

'We pray to you.'

After $i$ 'and' (not a potential clitic host in ocs; Sławski 1946:25)

(7) J. $16.32\left(\mathrm{~A}, \mathrm{~s}^{15}\right)$ :

$i$ mę edinogo ostavite

and me.ACC.SG alone.GEN.-ACC.SG leave.2.PL

k'amè mónon aphête

'and shall leave me alone.'16

11 The general facts on the distribution of the accusative (tonic and clitic) vs. genitive (rare and tonic) of the personal pronouns are well known. See for example, van Wijk 1931:198;

Diels 1963:214.

12 But $\mathrm{S}$ has vasŭ and mene.

14 The English translations of the Gospels are from the King James Bible.

15 But M, Z, O, v mene.

16 See Appendix A for further examples. 


\section{After prepositions ${ }^{17}$}

J. $1.14(\mathrm{~A}, \mathrm{z}, \mathrm{O}):$
$i \quad$ vŭseli sę vŭ ny
and settled.3.sG REFL in us.ACC.PL
kai eskénōsen en hèmîn
'and (the Word) dwelt among us.'

Cf. Novgorod na mja 'on me' (no. 527, 1050-1075), na tja 'on you' (no. 862, 11001120). Middle Bulgarian accents $m e ̨$ in za mę, etc. and Štokavian záme < ${ }^{*} z \bar{a} ' m e ̨$ is consistent with retention of a long vowel in pretonic position. ${ }^{18}$

\section{$5 \quad$ The Distribution and Spread of the Pronominal Genitive-Accusative}

Apparently the first change affecting this system was the introduction of gen.acc. forms (mene, tebe, sebe, nasŭ, vasŭ). In the oldest ocs texts they are very rare. ${ }^{19}$

17 The accusative forms are the norm after prepositions in ocs. For the ist sg., for example, in

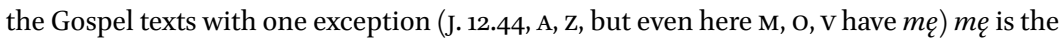
only form: vŭ mę (M. 18.6, 18.21, Mr. 9.42, J. 7.38, 11.25, 11.26, 12.44 (first occurrence), 12.46, 14.1, 14.12, 16.9, 17.20) na me (L. 22.53, J. 13.18). For the reflexive, sebe is the form of choice after $v \breve{u}$ (L. 11.18, L. 15.17, 18.11); vŭ sę does not seem to occur in ocs although na sę is just fine (Mr. 3.26, M. 27.42).

18 For Middle Bulgarian see Hock 1992 I:120. Exactly which intonation to reconstruct is uncertain. See Kapović 2006:81-82.

19 The counts are my own based on the available indices. Figures for $\mathrm{z}$ according to Moszyński 1990:151-152: mę 149× vs. mene $13 \times$; te $77 \times$ vs. tebe $1 \times$; sę $1130 \times$ vs. sebe $6 \times$; ny $17 \times$ vs. nasŭ o×; vy $74 \times$ vs. vasŭ 6 . For the Euch. Sin. me $79 \times$ vs. mene $2 \times$ (once as object of nominalized participle 85 a 16 lovęštiixŭ mene "of those hunting me" once (85a 22) in secondary predication); tę $105 \times$ vs. tebe $1 \times$; se (a lot) vs. sebe $3 \times$. nasŭ $1 \times$ and vasŭ $2 \times$. The Zograph palimpsest has 3 instances of $v y, 2$ te and 1 of $m e ̨$. The Enina Apostolos has $m e ̨ 8 \times$ vs. mene $0 \times$, tę $10 \times$ vs. tebe $0 \times$ ny 11 vs. nasŭ $2 \times v y 2 \times$ vs. vasŭ $0 \times$. The Freising monuments have $m e \quad 4 \times$, vs. mene $0 \times$; no examples of the 2 nd sg. acc.; ze $17 \times$ vs. * $z e b e($ sebe) $0 \times$, acc. $n i 2 \times, n a s(\breve{u})$ ox; Freising also has one instance of $v i$ as and pl. dative form (I.34 ese vi iest ugotoulieno "which is prepared for you."). For M. van Wijk 1926:262 counted ny $18 \times$ vs. nasŭ o×, vasŭ $2 \times$. 


\begin{tabular}{|c|c|c|c|c|c|c|c|c|c|c|}
\hline & \multicolumn{2}{|c|}{$\begin{array}{l}\text { K, Glg., } \\
\text { mid 1oth }\end{array}$} & \multicolumn{2}{|c|}{$\begin{array}{l}\text { A, Glg., } \\
\text { 1oth }^{20}\end{array}$} & \multicolumn{2}{|c|}{$\begin{array}{l}\text { c, Glg., } \\
\text { 11th }\end{array}$} & \multicolumn{2}{|c|}{$\begin{array}{l}\text { Ps. Sin., Glg., } \\
\text { 1 1th }^{21}\end{array}$} & \multicolumn{2}{|c|}{$\begin{array}{c}\text { Supr., Cyr., } \\
\text { 1 th (2nd half) }\end{array}$} \\
\hline & acc. & $\mathbf{g} / \mathbf{a}$ & acc. & $g / a$ & acc. & $g / a$ & acc. & $\mathbf{g} / \mathbf{a}$ & acc. & $\mathbf{g} / \mathbf{a}$ \\
\hline $1 \mathrm{sg}$. & 0 & o & 147 & 2 & 3 & 0 & 125 & 2 & $15^{8}$ & 22 \\
\hline $2 \mathrm{sg}$. & 17 & o & 57 & o & 11 & 1 & 31 & 4 & 106 & $8^{22}$ \\
\hline refl. & 7 & o & 46 & 2 & 23 & 6 & $>100$ & 3 & $*$ & 41 \\
\hline $1 \mathrm{pl}$. & 33 & $\mathrm{o}^{23}$ & 13 & o & 10 & $3^{24}$ & 10 & 5 & $5^{1}$ & $5^{\circ}$ \\
\hline $2 \mathrm{pl}$. & o & 0 & 71 & 1 & 1 & 1 & o & o & 27 & 22 \\
\hline
\end{tabular}

Almost all the occurrences of the gen.-acc. are in a position where a clitic would normally not be permitted. In sentence-initial position:

(9) M. $18.5(\mathrm{M})$ :

$i \quad$ iže koližŭdo priimetŭ otroče

and who.NOM.sG ever will-receive.3.sG child.AcC.sG

takovo edino vŭimę moe mene

such.ACC.SG one.ACC.SG in name.ACc.sg my.ACC.SG me.GEN.-ACC

priemletŭ

receive.3.SG

kai hòs eàn déksētai hèn paidion toioûto epì tồi onómatí mou, emè dekhetai. 'And whoso shall receive one such little child in my name receiveth me.'

In some sort of stressed position: Corrective focus ${ }^{25}$

20 But some argue for a later date. See Garzaniti 2001:314.

21 Combining both the Ps. Sin. and the Psalterium Sinaiticum Novum.

22 Since Meyer 1935 doesn't separate the gen.-acc. from the genitives for the 2 nd person form, I give the gen.-acc. forms here in the pagination of the ms.: 2v.11, 24v.6, 66r.26, 116v.25, 149v.24, 156r.8, 235r7, 20.

23 The form nasŭ in $i$ verra tvoeja vŭ nasŭ da vŭzdrastetŭ et fides tua in nobis ut succrescat. "And may your faith grow in us" is almost certainly a locative.

24 van Wijk 1926:263 was suspicious of the antiquity of two of these cases.

25 For a recent discussion of focus types see Riester and Baumann 2013. In their approach corrective focus is merely an extreme case of contrastive focus. Contrastive focus differs from novelty focus in that while both generate a focus semantic value defined as a set of individuals of the same semantic type as the focused constituent, contrastive focus is 
(10) J. $12.44(\mathrm{~A}, \mathrm{z}):^{26}$

věrujęi vŭ mę ne věruetŭ vŭ

believe.PTCP.NOM.SG in me.ACC.SG not believe.3.sG in

mene nŭ vŭ posŭlavǔšaego mę

me.GEN.-ACC.SG but in send.PAST.PTC.GEN.SG me.ACC.sG

ho pisteúōn eis emé ou pisteúei eis emé, allà eis tòn pémpsantá me

'He that believeth on me, believeth not on me, but on him that sent me.'

Contrastive focus

(11) J. 7.28 (M, Z, A O, v):

$i$ mene věste $i$ věste otŭ kqdy

and me.GEN.-ACC.SG know.2.PL and know.2.PL from whence

esmŭ

am.1.sG

k'amè oídate kai póthen eimí

'Ye both know me, and ye know whence I am' (But you don't know the one who sent me (egože vy ne věste))

(12) J. $15.20(\mathrm{M}, \mathrm{Z}, \mathrm{S}, \mathrm{O}):^{27}$

ašte mene izgŭnaše $i \quad$ vasŭ

if me.GEN.-ACC.SG persecuted.3.PL and you.GEN.-ACC.PL

iždenqtŭ

persecute.3.PL

ei emè edíoksan, kai humâs dióksousin

'If they have persecuted me, they will also persecute you.'28

Before an apposition at an intonational phrase boundary

(13) L. $12.28(\mathrm{M}, \mathrm{z}):^{29}$

kolĭmi pače vasŭ, malověri (oděetŭ)

how much more you.GEN.-ACC.PL of little faith.VOC.PL dress.3.sG pósōi mâllon humâs, oligópistoi?

'How much more [will he clothe] you, O ye of little faith?'

also associated with an anaphoric operator that permits the identification of at least one alternative with certainty. See Rooth 1992.

26 But M, o, v mę.

27 But A, N have $m e$, , vy.

28 See Appendix в for further examples.

$29=$ M $6.30 \mathrm{~A}, \mathrm{z} \mathrm{O}, \mathrm{M} \mathrm{S}$. 
(14) J. $17 \cdot 3(\mathrm{M}, \mathrm{z}, \mathrm{S}, \mathrm{v}):^{30}$

da znajqtŭ tebe edinogo

COMP know.3.PL you.GEN.-ACC.SG one.GEN.ACC.SG

istinünago boga

true.GEN.ACC.sG god.GEN.ACC.SG

hína ginốskōsin sè tòn mónon alēthinòn theón

'that they might know thee, the only true God.'

(15) $8 \mathrm{~b} 30-31(\mathrm{c})$ :

tebe, vraga sqšta

you.GEN.-ACC.SG enemy.GEN.-ACC.SG.M be.PTCP.GEN.-ACC.SG.M

$i$ protivna, $i$ chote $e^{31}$

and hostile.GEN.-ACC.SG.M and want.PTCP.NOM.SG.M

druga sŭtvoriti

friend.GEN.-ACC.SG make.INF

ekhthròn ónta se kai polémion hína poiésēi phílon

'wanting to make you, being hostile and an enemy, a friend'

As subject of secondary predication

(16) $2 \mathrm{~b} 28$ (c):

ispovědaje sebe věrna

declare.PTCP.NOM.sG.M ref.GEN.-ACC.sG. faithful.GEN.-ACC.sG.M 'declaring himself faithful'

(17) L. $23.2(\mathrm{M}, \mathrm{z}):^{32}$

g̃ljošta sebe $\tilde{x} a$

say.PTCP.GEN.-ACC.SG.M REFL.GEN.-ACC. Christ.GEN.-ACC.SG.M

črě byti

king.GEN.-ACC.SG.M be.INF

légonta heautòn khristòn basiléa eînai

'saying that he himself is Christ a King.' 33

Note that in English and German the subject of a resultative secondary predication receives a focus accent (Winkler 1997:282, 291):

30 A te.

32 But the significantly later scs Miroslav gospel has se here.

33 See Appendix c for further examples. 
(18) English

The ${ }_{\mathrm{F}}$ gárdener] watered the ${ }_{\mathrm{F}}$ lílies] flat.

(19) German

Dort fegt der Wind den

[ ${ }_{F}$ Himmel] blank.

there sweeps the.Nom.sG.M wind the.Acc.sG.m heaven clear

'There the wind sweeps the sky clear.'

In depictive secondary predication the focus accent is assigned to both the subject and the depictive predicate.

(20) English

He ate méat ráw.

(21) German

Er isst Lámm róh.

he eats lamb raw. ${ }^{34}$

Associated with focalizing elements

(22) Mr. 12.31(M): ${ }^{35}$

v̆zljubiši iskrĭněgo svoego ěko samŭ

love.2.SG neighbor.GEN.-ACC.SG.M own.GEN.-ACC.SG.M as self

sebe

REFL.GEN.-ACC

Agapếseis tòn plēsíon sou hōs seautón.

'Thou shalt love thy neighbour as thyself.' 36

(23) Mr. 12.33 (M, Z, A):

$i$ eže ljubiti iskrĭněago ěko

and REL.NOM.SG.N love.INF neighbor.GEN.-ACC.SG.M as

sebe

REFL.GEN.-ACC

kaì tò agapân tòn plēsíon hōs heautòn

'And to love his neighbor as himself.'

35 But A, z se (absent in s). A adds $i$ before samŭ. Miroslav too has $s e$.

36 But at M. 22.38 has v̌zljubiši iskrĭnjago tvoego jako samŭ sę (M, A, Z, also Miroslav). M. 19.6 o has jako samŭ sę as well. 
Unclear

(24) M. $17 \cdot 17(\mathrm{M}, \mathrm{O}):^{37}$

dokolě trŭpljo vasŭ

how-long endure.1.sG you.GEN.-ACC

héōs póte aneksómai humồn

'How long shall I suffer you?'

The previous sentence is dokolě sŭ vamui bqdq "How long shall I be with you!" so there is probably some sort of emphasis on 'you'.

(25) Man. 15 (25b8 PSN): ${ }^{38}$

jako tebe pojetŭ v̌sěka sila

as you.GEN.-ACC praise.3.SG all.NOM.SG.F host.NOM.SG.F

nbsnaja

heavenly.NOM.sG.F

'For all the powers of the heavens do praise thee.'39

The choice of acc. or gen.-acc. is not determined by the Greek. In the Gospels Gk. stressed accusative emé 'me' as Do is often translated mę if in a nonnegated construction not following a Slavic verb requiring a different case. ${ }^{40}$ Only a subset of the instance of emé are translated with mene in either some or all of the manuscripts. The cases where Gk. emé is unanimously translated with the ocs accusative seem to be predominantly noncontrastive.

37 But A, s vy.

38 But the Psalterium Bononiense has te .

39 After a preposition the old accusative forms are quite resistant. An example like PSN 310 15L (= 32a 27, similar formula 31b 19, 20, and elsewhere):

Boqdi milostı̆ $\bar{g} i \quad$ tvoja $\quad$ na nasŭ.

be.IMP lord.voc.sg mercy.NOM.sG.F your.NOM.sG.F on us génoito, Kúrie, tò éleós sou eph' hēmâs

'Let thy mercy, O LORD, be upon us.'

probably contains a locative, which often translates Gk. epi plus the accusative.

40 For further examples see Appendix D. 
(26) J. $16.14(\mathrm{M}, \mathrm{Z}, \mathrm{A}, \mathrm{s})$ :

Onŭ mę proslavitŭ

he me.ACC.SG glorify.3.sG

ekeînos emè dóksasei

'He (the paraclete) shall glorify me.'

The Birchbark Documents from Novgorod. ${ }^{41}$ According to Zaliznjak 2004:106, 2008:137 there are basically no examples of gen.-acc. in personal pronominal forms in the oldest period and only very few from the end of the 12th century onward. ${ }^{42}$ Other Old Russian texts show an encroachment of genitive forms beginning with the plural. The fact that the genitive forms are quite uncommon in ocs or even unattested in early Novgorodian does not in itself mean that they are an innovation. The genitive forms occur only under very specific conditions, basically some kind of focus. The necessary conditions for this environment are presumably fairly infrequent and it is not surprising that they do not occur in the mainly very short early letters.

What is more significant is the fact that the old accusative forms were still viable options for the focus positions in ocs. There is only one Gospel passage transmitted unanimously in $\mathrm{M}, \mathrm{z}, \mathrm{A}, \mathrm{O}$ and $\mathrm{V}$ with the genitive:

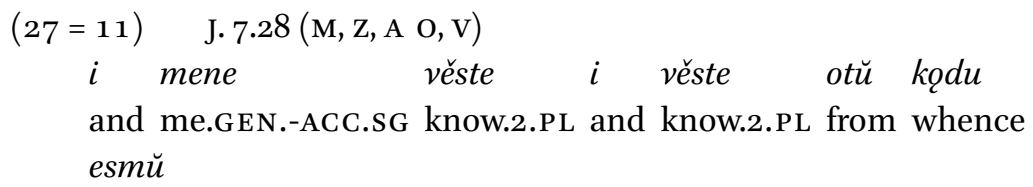

All others have the accusative in at least one manuscript. This is good evidence that the gen.-acc. in pronominal forms is fairly recent.

\footnotetext{
41 I have chosen to focus on the Novgorod documents rather than on Old Russian manuscripts because they are less influenced by ocs norms and because they are of great antiquity and are directly transmitted.

42 An early example may be и позовало мене во погосто "and he called me into the churchyard." (531, 1200-1220).
} 
If the gen-acc. in pronominal forms is recent, how about the nominal gen.acc.? The gen.-acc. for nominal forms was firmly established within its original sphere of usage in ocs and probably in Novgorod. The ocs manuscripts do not vary between acc. and gen.-acc. for (1) substantivized singular definite adjectives and participles referring to male persons and (2) $O$-stem male personal names. ${ }^{43}$ As is well known, an important factor that favors the gen.-acc. is the physical and social status of the referent. In ocs and on healthy, free, male, persons, i.e. persons most capable of exercising agency, tend to take the gen.-acc. ${ }^{44}$ It is probable that $o$-stem masculine personal names are simply prototypical representatives of the healthy, free, male category, and, in addition, are always definite, a factor known to favor D om elsewhere. ${ }^{45}$ This second category, $o$-stem male personal names, is precisely the one that according to Zaliznjak (2004:106) always shows the gen.-acc. in Novgorod. ${ }^{46}$

Kwon 2009:44 claims (1) that in these Novgorod documents the gen.-acc. is observed earlier in the plural and (2) "the gen.-acc. $-a$ in the declension of masc. sg. $o$-stems began to appear in the 2nd half of the $13^{\text {th }}$ century and was fixed only in the 14th to 15th century" (citing Krys'ko 1993, 1994) ${ }^{47} \mathrm{Ad}(1)$ I don't know exactly what is being referred to here. As far as I can tell there is no evidence

43 See Vaillant 1964:178. Lunt's statement (2001:144) "Personal names tend to keep the accusative form" is just not correct. A corpus study of $\mathrm{M}$ by Eckhoff (p. 6) finds that all proper names take the gen.-acc. But as an anonymous reviewer points out, there is one example of an $o$-stem personal name in the accusative in $\mathrm{z}(\mathrm{J} 8.57$ abraamŭ li esi vidělŭ "and hast thou seen Abraham?"). This might be a simple error. $\mathrm{M}$ and A have the expected gen.-acc. form. Note that the gen.-acc. is governed by both semantic and morphological factors. Non- $o$ stem masculine personal names, for example, do not show the gen.-acc. in ocs, e.g. Mt. 1.10 (As. Sav., Ost.): Amoš̌že rodi Iosajo “Amos begat Josaiah.” with Iosajo the acc. of Iosaja, a masculine a-stem.

44 See e.g. Janda 1999:205.

45 Unfortunately there are, to my knowledge, no crucial cases of named unhealthy or unfree males in the Gospels. Slaves and the sick are normally not given names. The stories of Bartimaeus, the blind man, and Lazarus, the dead man, the two named sick men I know of, simply don't provide the requisite structures.

46 And the or of the Laurentian ms. of the Primary Chronicle also almost always uses the gen.-acc. for masculine personal names. See Klenin 1987:407.

47 In fact, Krys'ko 1993:69 says that in the documents from the 11th to 13th centuries we find 8 forms of the gen.-acc. vs. 15 forms of the accusative. Four of these eight are suspect of being nonnative forms, but four (really three) are unimpeachable. See the next note. 
for the gen.-acc. for masculine plurals in the $o$-stems. The genitive ending is $-\breve{u}$ (often written $o$ ) and the masc. acc. pl. is -ě. Ad (2) gen.-acc. $-a$ is attested as early as 1025-1050 in no. 247:

(28) Novg. 247

a prodai klevetĭnika togo

PTC punish.IMP informer.GEN.ACC.SG this.GEN.ACC.SG

'Fine this slanderer.'48

The inference is that the nominal gen.-acc. is older than the pronominal one.

Gendered pronouns behave like nouns rather than personal pronouns. In ocs the gen.-acc. for gendered pronominals is found, with a few exceptions, only in the singular (at J 5.21 $\mathrm{z}$ has the gen.-acc. sg. jegože but $\mathrm{M}$ and $\mathrm{A}$ have the acc. pl. jęže) and is sensitive to animacy. ${ }^{49}$

Different gendered pronouns have different rates of innovation. For the suppletive pronoun nom. on $\breve{u}$, acc. $i<{ }_{j j} \breve{~ t h e ~ a c c u s a t i v e ~ f o r m ~ w i t h ~ h u m a n ~}$ reference is the most common. The gen-acc. jego is quite rare. For example in C there are 17 instances of $i$ with human reference vs. only two cases of jego $(13 \mathrm{a} 13,13 \mathrm{~b}$ 19). In A there are well over a hundred instance of $i$, the majority of them with human referent, vs. only 4 cases of jego (89a 28a, 107a $7 \mathrm{a}, 11 \mathrm{~b}$ 10a, $119 \mathrm{~b} 24 \mathrm{a})$. The figures for $t \breve{u}$ 'this', which has the accusative $t \breve{u}$, are similar.

On the other hand, the replacement of the gen.-acc. for the acc. in the relative pronoun has gone much further and is practically the norm. In A there are 33 instances of jegože vs. 16 of $i \check{e}$ some of which may have non-human reference. In the parallel passages in $\mathrm{z} \mathrm{M} A$ and $\mathrm{s}$ there are 36 instances where gen.-acc. jegože is the unanimous reading of however many manuscripts attest the verse in question. There are only 3 cases where there is some disagreement, for which a number of different explanations are required.

48 A second instance of gen.-асс. клеветьника in 247 has the crucial final vowel restored. In addition we have моли Воньзда "ask Vnezd." (82, 1180-1200), на Домажировица (510, 1220-1240), на Ивана (897, 1120-1140).

49 There are a few scattered examples of the extension of the gen.-acc. to the plural. At L. 6.32 $\mathrm{M}$ and $\mathrm{s}$ read ljubęšteję ixŭ 'loving them' $\mathrm{z}$ and A have just ljubęšteję. Both perhaps are employing different strategies for avoiding *ljubęšteje ję. As alone has the gen. pl. at Mt. 8.16 vsěxŭ bolęštixŭ icěli "He healed all the sick" and at J. 17.6 ixŭže dastŭ mi "whom you gave to me'. 
At J. 4.22

(29) vy klaněte sę egože ne věste my že you worship.2.PL REFL whom.GEN.SG not know.2.PL we PTC klaněemŭ se egože/eže věmŭ worship.1.PL REFL whom.GEN.-ACC.SG./ACC.SG know.1PL humeîs proskuneîte hò ouk oídate hēmeîs proskunoûmen hò oídamen 'Ye (Samaritans) worship ye know not what; we worship whom/what we know.'

In the first sentence the gen. is regular after the negation. In the second, $\mathrm{M}$ has $e \check{z}$, but A egože. This may result from uncertainty about animacy of reference. The Greek original has the neuter hò, but the natural inference is that the Jews worship God.

In two other cases we may see the interaction of syntax and phonology. At $\mathrm{J}$. 19.37 $\mathrm{Z}$ has a gen.-acc. for the pronoun $i$ after a preposition and the acc. for the relative pronoun:

(30) vŭžrętŭ na n'ego iže probase

look.3.PL on him.GEN.-ACC.SG REL.ACC.SG pierced.3.PL.

'They shall look on him whom they pierced.'

But $\mathrm{M}$ and $\mathrm{A}$ have the accusative of the pronoun and the genitive of the relative na n’̌ egože probasę. The latter is what may be considered the general pattern since the accusative $i$ is especially resistant to replacement after prepositions ${ }^{50}$ and, as we have said, the gen.-acc. is the norm for the relative. Thus we may suppose that if the gen.-acc. were to be introduced we would expect *na $n^{j}$ ego jegože and that this was replaced by na $n^{j}$ ego iže to avoid cacophony. ${ }^{51}$ Likewise at Mr. $14.71 \mathrm{z}$ has eže, but $\mathrm{M}$ has egože.

$50 \quad n a n \check{\iota}<*$ *na $n-j \check{~} \breve{~ i s ~ r e t a i n e d ~ i n ~ t h e ~ S e r b i a n ~ C h u r c h ~ S l a v o n i c ~ M i r o s l a v ~ E v a n g e l i u m . ~ P r o n o m-~}$ inal accusatives survive into modern times with no animacy distinctions in Slov. vánj 'on him/it', zánj, SCr. zâ nj 'for him/it' (confirmed by Draga Zec). See Nahtigal 1961:213. The replacement of the acc. by the gen.-acc. seems to have come first to direct objects and only subsequently to prepositional objects. There are quite a few prepositional objects in the accusative with human referent in the Gospels, e.g. J. 6.29 vŭ tŭ, Mr. 10. 12 za n'üu, and even with the relative pronoun Mt. 12.18 na n'iže, J. 1.33 nadŭ n'̌že.

51 Schulze 1906:612. 


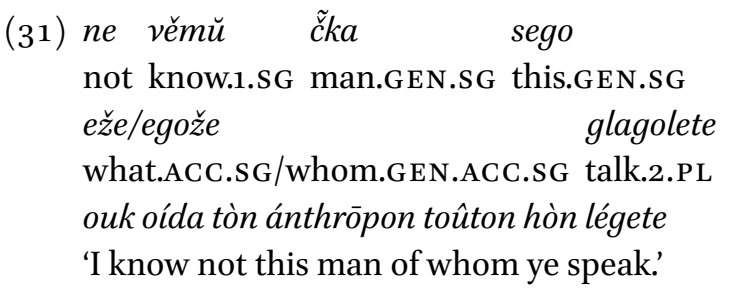

\section{$7 \quad$ Connecting the Two Genitive-Accusatives}

Obviously the genitive and the accusative are closely related in Slavic with the genitive regularly replacing the accusative under negation, for example. Meillet 1897 argued that the nominal gen.-acc. had its origin in an original pronominal gen.-acc. *teue *mene. ${ }^{2}$ There is no evidence for the accusative function of the forms *teue *mene outside of Slavic and in fact the Indo-Iranian cognates are exclusively genitive. Berneker 1904:369. ${ }^{53}$ The innovative character of the pronominal gen.-acc. as argued for above makes the pronouns an unlikely starting point for the innovation. Kuryłowicz 1962 still seems the most straightforward explanation of how the nominal gen.-acc. could have got its start: Neg. + part. gen. : part. gen. :: Neg. + gen. : $x, x=$ gen. (still one needs additional machinery to explain why only animate $o$-stem names were affected). ${ }^{54}$ If this account is correct then we would have a potentially theoretically interesting case of DOM in human proper nouns but not in pronouns. ${ }^{55}$

In order to account for the pronominal facts we need to explain the following differences: (1) The genitive pronominal forms are found in both singular and plural, unlike the nominal forms. (2) The genitive pronominal forms are typically associated with focal stress or some other intonational marking. One and

$5^{2} \quad$ van Tilburg 1988:595-596 argues that the observed extensions of the gen.-acc. to the plural pronominal forms either predominantly (Rešetar 1898:187 on 15th century SCr.) or earlier than the further extension to nominal forms supports Meillet's claim.

53 The East Baltic facts might be interpreted as pointing to a onetime accusative function of the genitive, but Old Prussian shows through its accusative forms mien, tien, sien, exactly matching ocs, that this cannot be old.

54 As one of the referees notes, this problem may be serious enough to rule out Kuryłowicz's account. In that case, the exact origin of the gen.-acc. - $a$ is still a mystery to be solved.

55 Or maybe not. First and 2nd personal pronouns have exclusively animate reference (except in metaphorical contexts like speaking inscriptions!) but they do not necessarily refer to humans (we can address dogs and cats, for example, with and person forms). 
only one form provides the bridge between nominal and pronominal forms, viz. $k o g o$, the old genitive of the interrogative-indefinite kŭto. ${ }^{56}$ The nominal gen.acc. is used primarily to mark nouns that score high on the animacy hierarchy. Kŭto is the only pronominal form to make an animate/inanimate contrast. ${ }^{57}$ The nominal gen.-acc. occurs only in the singular in Ocs and OR. The pronominal gen.-acc. is found in all three numbers. ${ }^{58}$ Kŭto is number-indifferent and thus provides a model for the extension of the pattern to the plural. Like the $o$ stems, the nom. and acc. of kŭto would have been identical. Avoidance of this homonymy is often cited as a motivation for the nominal gen.-acc. innovation. (Kuryłowicz 1962 inter alios). ${ }^{59}$

But it is noteworthy that Novgorodian has an $o$-stem nominative in $-e$ and accusative in $-\breve{u}$, and also the interrogative $k e t o^{60}$ (and thus had no nom.acc. homophony). ${ }^{61}$ If Olander 2012 is correct that * ${ }^{*}$ os gave * ${ }^{*}$ in ProtoSlavic which merged with $\breve{u}$ in all forms of Slavic except Novgorodian where it merged with $e$, then a Proto-Slavic nom.-acc. homonymy could not have been a crucial factor in the creation of the gen.-acc. It seems to me that the vocative hypothesis (recently Kwon 2009) has not been adequately refuted. The main objection seems to be that the wholesale morphological replacement of the nominative by the vocative is typologically unparalleled (so Zaliznjak 2004:148), but this is exactly what appears to have happened in the Latin ist declension nom. sg. in - $\breve{a}^{62}$

Unlike the personal pronouns, the gen.-acc. kogo is the only form found in ocs Gospels. (Diels 1963:97: "The accusative is lacking. It is always represented by the genitive kogo.") My examination of the Gospels confirms this.

56 The important role of the interrogative pronoun has been noted before, e.g. by Vondrák 1908:340: "Der Impuls zum Gen.-Akk. ging also wohl vom urslav. kogo aus. Da mit kŭto-kogo nach Personen gefragt wird, so sind davon zunächst auch die Personennamen tangiert worden und zwar aus dem angegebenen Grunde zunächst die o-St., welche männlicher Personen bezeichneten." Huntley 1980:205. But these accounts take kogo as the starting point for the spread of the gen.-acc. to nouns.

57 The loss of a distinct feminine is in itself an innovation. For traces of the expected ${ }^{*} k a$ throughout Slavic see Boryś 2005:226, s.v. każdy, Majer 2012:226.

58 Cf.J. 6.64kŭto sqtŭ nevěrujoštei [tínes eisin hoimè pisteúontes] "who they were that believed not" (an indirect question) where the Greek has an explicit plural.

59 See also Klenin 1987 and Bratishenko 1998, 2003.

6o Staraja Rjazan' 12 and Novgorod itself in the form ketŭ (892, 1120-1140). Zaliznjak 2004:125.

61 For a review of theories about this phenomenon see Olander 2012.

62 One referee notes the absence of palatalization is another serious obstacle to the vocative hypothesis. This would have to be explained analogically. 
(32) M.16.13 (M, Z, A): 63

kogo g̃ljotŭ me člvci

who.GEN.-ACC say.3.PL me.GEN.-ACC men.NOM.PL.M

sqšta sna

be.PTCP.GEN.-ACC.SG.M Son.GEN.-ACC.SG.M

člvčskaago

mannish.GEN.-ACC.SG.M

tína légousin hoi ánthrōpoi eînai ton huiòn toû anthrốpou

'Whom do men say that I, the Son of man, am?'64

The extension of DOM specifically to the interrogative is also found in Persian. ${ }^{65}$

(33) Modern Persian

man hasan râ didam

I Hasan DEF saw

'I saw Hasan.'

(34) Modern Persian

to ke râ didi?

you.sG who DEF saw

'Whom did you see?'

The forms of kŭto in interrogative function may have been characterized intonationally. In Serbo-Croatian the wH-word, unlike English, generally has a higher pitch.

(35) Serbo-Croatian

KAKO to radite?

how that do.2.PL

'How are you doing that?'

KO dolazi?

who comes.3.sG

'Who is coming?'

63 byti instead of sqšta.

64 See Appendix E for examples of kogo from the Gospels.

65 Browne 1970; Cf. also Finnish where the accusative marker $-t$ is added to the human personal pronouns and to the human interrogative. See Comrie 1979:16. 
KOGA ste pozvali?

who.GEN.-ACC be.AUX.2.PL invite.PTC.PL.M

'Who did you invite?'

ŠTA znaš?

what know.2.sG

'What do you know?'

Lehiste and Ivić 1986:207 report that in ten sentences introduced by kada 'when', the average $\mathrm{F}_{0}$ peak was at $26 \mathrm{gHz}$; the next word, which is comparable to the first word of a simple statement, had an average $F_{0}$ peak of $235 \mathrm{~Hz}$ followed by a regular decline. The $\mathrm{F}_{0}$ on the first word of the ten corresponding statements was $230 \mathrm{~Hz}$. This raised pitch is comparable to "emphasis" in a declarative sentence. ${ }^{66}$

Bulgarian shows the same pattern as can be seen from the Praat spectrogram with pitch track below:

\section{(36) Bulgarian}

Koj otide da vzeme deteto ot učilište?

who goes that gets child-the from school

'Who is going to get the child from school?'

Serbo-Croatian and Bulgarian are not ocs, but we will never know ocs sentence prosody. Russian and Polish are similar. Thus it is not improbable that this intonation was characteristic of Proto-Slavic. ${ }^{67}$ This would explain why the early personal pronominal gen.-acc. show the distribution they do, as stressed (often focused) variants. In particular, the extension from $\mathrm{Q}>\mathrm{A}$ seems natural.

66 For the acoustic correlates of focus in English see Breen et al. 2010.

67 According to Buning and Schooneveld 1961:11 wH questions have the same general intonation pattern as declarative sentences, i.e. a drop on the final stressed syllable, but in their annotated example któ is the highest pitch in the sentence. Comrie 1984:24 notes that the intonational nucleus is on the wH-word KTo ljubit Tanju? "Who loves Tanya?" In Comrie's view "carrying over the location and contour of a Russian special question into English gives rise to a distinct sensation of aggressive hostility." See also Yokoyama 1987:265 on the Type II (sentence accent on the wH-word) intonation characteristic of "impositional" questions, which today at least is the most typical question intonation. The intonation of questions in Russian appears to be quite complicated. See also Yokoyama 2009. 


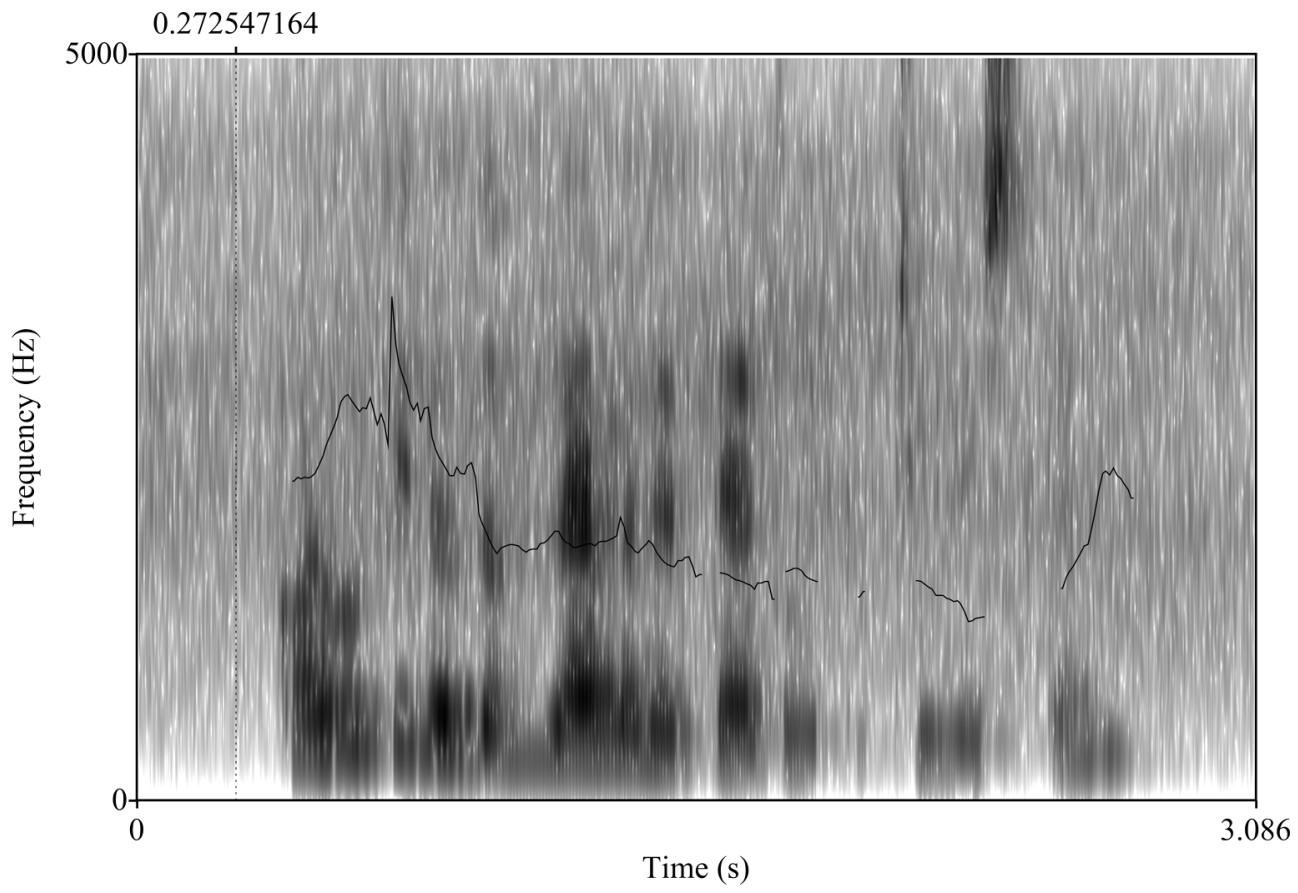

FIGURE 1 Spectrogram with pitch track for Koj otide da vzeme deteto ot učilište?
Q: kogo pogrebeši?
A: tebe (pogrebo)!
Whom are you burying?
(I’m burying) you!

In fact, according to a formulation first introduced by Hermann Paul (1880:283) the focused information is the part of the sentence that answers the WH-part of WH-questions. ${ }^{68}$

\section{$8 \quad$ Conclusions}

The gen.-acc. pronominals are employed in an intonationally marked context, predominantly focus. The gen.-acc. originates in $o$-stem personal names (as prototypically free, male, definite referents) in direct object function and spreads from there first to the interrogative pronoun already in Proto-Slavic. From these two bases the gen.-acc. spreads along two vectors. On the one hand,

68 Of course, there are complications. See Goedegebuure 2009 for one recent discussion of focus and questions. 
the gen.-acc. is extended as a marker of higher animacy to the gendered pronouns (first of all to the relative pronoun) and to $o$-stem substantives with human referent. These extensions were not complete in Proto-Slavic and there are significant traces of the old accusative forms in these categories in the historically attested Slavic languages. On the other hand, the extension from the interrogative gen.-acc. kogo 'whom' to the personal pronouns crucially involved a re-mapping of the animacy distinction into a tonicity distinction. This extension too was only incipient in Proto-Slavic. The creation of new distinctively tonic personal-pronominal forms accelerated the downgrading of the old tonic forms to clitics. ${ }^{69}$ The cliticization of old tonic pronouns and their replacement by new tonic forms is a pattern that reoccurs in a wide variety of Indo-European languages (e.g. Latin and Romance) and which perhaps deserves to be called a close cousin of Jespersen's Cycle.

\section{References}

Aissen, J. 2003. “Differential Object Marking: Iconicity vs. Economy." Natural Language and Linguistic Theory 21:435-483.

Berneker, E. 1904. “Der genitiv-akkusativ bei belebten Wesen im Slavischen." Zeitschrift für vergleichende Sprachforschung 37:364-386.

Boryś, W. 2005. Stownik etymologiczny języka polskiego. Cracow: Wydawnictwo Literackie.

Bossong, Georg. 1984. "Animacy and Markedness in Universal Grammar." Glossologia 2-3:7-20.

Breene, Mara, Evelina Fedorenko, Michael Wagner and Edward Gibson. 2010. "Acoustic Correlates of Information Structure." Language and Cognitive Processes 25:7-9:10441098.

Browne, E. Wayles. 1970. "More on Definiteness Markers: Interrogatives in Persian." Linguistic Inquiry 1:359-363.

Buning, J.E. Jurgens and C.H. van Schooneveld. 1961. The Sentence Intonation of Contemporary Standard Russian as a Linguistic Structure. The Hague: Mouton.

Bratishenko, Elena. 1998. Morphosyntactic Variation in Possessive Constructions and the Accusative in Old East Slavic Texts. University of Toronto Ph.D. dissertation.

69 One of the reviewers remarks that this paper does not explain the tonicity downgrade of the old accusative pronouns. It seems to me that loss of tonicity for originally stressed pronominal forms is so widespread cross-linguistically and so natural a consequence of semantic bleaching that no special explanation is required. 
Bratishenko, Elena. 2003. "Genitive-Accusative and Possessive Adjective in Old East Slavic." Scando-Slavica 49:83-103.

Comrie, Bernard. 1979. "Definite and Animate Direct Objects: A Natural Class." Linguistica Silesiana 3:13-21.

Comrie, Bernard. 1984. "Russian." In Interrogativity, edited by W. Chisholm et al., 7-46. Amsterdam: John Benjamins.

Diels, Paul. 1963. Altkirchenslavische Grammatik: mit einer Auswahl von Texten und einem Wörterbuch. Heidelberg: C. Winter.

Dobrev, I. 1971. "Palimpsestovite časti na Zografskogo evangelije." In Konstantin Kiril Filosof, edited by B. Angelov et al., 157-164. Sofia: Bălgarskata Akademija na Naukite.

Dostál, Antonín. 1959. Clozianus. Staroslověnský hlaholský sborník Tridentský a Innsbrucký. Prague: Czechoslovak Academy of Sciences.

Eckhoff, Hanne. n.d. "Animacy and Differential Object Marking in Old Church Slavonic." on Academia.edu.

Garzaniti, Marcello. 2001. Die altslavische Version der Evangelien. Cologne: Böhlau.

Goedegebuure, Petra. "Focus Structure and Q-Word Questions in Hittite." Linguistics 47:945-969.

Grünenthal, O. 1910. "Die Übersetzungtechnik der altkirchenslavischen Evangelienübersetzung." Archiv für slavische Philologie 31:321-366.

Hock, Wolfgang. 1992. Der Flexionsakzent im mittelbulgarischen Evangelie 1139 (NBKM), I: Akzentgrammatik, II: Akzentwörterbuch. München: Otto Sagner.

Huntley, David. 1980. "The Evolution of Genitive-Accusative Animate and Personal Nouns in Slavic Dialects." In Historical Morphology, edited by Jacek Fisiak, 189-212. Berlin: De Gruyter.

Janda, Laura. 1999. "Whence Virility? The Rise of a New Gender Distinction in the History of Slavic." In Slavic Gender Linguistics, edited by Margaret Mills, 201-228. Amsterdam: J. Benjamins.

Kapović, Mate. 2006. Reconstruction of Balto-Slavic Personal Pronouns with Emphasis on Accentuation. Ph.D. dissertation. Zagreb: Zadar.

Kiparsky, Valentin. 1967. Russische historische Grammatik, Vol. 2. Heidelberg: Winter.

Klenin, Emily. 1987. "Morphological Coding, Syntactic Change, and the Modes of Historical Attestation: The Genitive-Accusative in Old Church Slavonic and Medieval East Slavic." The Slavic and East European Journal 31:404-419.

Klenin, Emily. 2009. "Animacy, Personhood." In Die slavischen Sprachen, edited by S. Kempgen et al., 152-161. Berlin: de Gruyter.

Kowalewicz, Henryk and Kuraszkiewicz, W. 1972. "Staropolska pieśń maryjna na nowo odczytana." Archiwum Literackie 16:9-17.

Krăstanov, T. et al. 1996. Vatikansko Evangelie. Sofia: Sibal.

Krys'ko, Vadim Borisovič. 1993. "Kategorija oduševlennosti v drevnenovgorodskom dialekte". Slavjanovedenie 3.69-79. 
Krys'ko, Vadim Borisovič. 1994. "Kategorija oduševlennosti v drevnenovgorodskom dialekte". Slavjanovedenie 1.31-40.

Kuryłowicz, J. 1962. "Personal and Animate Genders in Slavic." Lingua 11:249-255.

Kwon, Kyongjoon. 2009. "The Early Development of Animacy in Novgorod." In Grammatical Change in Indo-European Languages, edited by Vit Bubenik et al. 43-53. Philadelphia: John Benjamins.

Lehiste, Ilse, and Pavle Ivić. 1986. Word and Sentence Prosody in Serbocroatian. Cambridge, MA: MIT.

Mardale, Alexandru. 2008. "Microvariation within Differential Object Marking: Data from Romance." Revue roumaine de linguistique 53:448-467.

Majer, M. 2011. "PIE * so, *seh, ${ }^{*}$ tod / PSl. *tz, *ta, *to and the development of PIE wordfinal *os in Proto-Slavic." In Indogermanistik und Linguistik im Dialog, edited by T. Krisch and T. Lindner, 352-36o. Wiesbaden: Reichert.

Majer, M. 2012. "An Archaic Indo-European Verbal Form in the Slavic Generalizing Particle *-žl̆do?" In The Indo-European Verb, edited by H. Craig Melchert, 225-234. Wiesbaden: Reichert.

Meillet, A. 1897. Recherches sur l'emploi du génitif-accusatif en vieux-slave. Paris: Bouillon.

Meyer, Karl H. 1935. Altkirchenslavisch-griechisches Wörterbuch des Codex Suprasliensis. Glückstadt: J.J. Augustin.

Moszyński, Leszek. 1990. Język kodeksu zografskiego, Vol. 2. Wrocław: Ossolineum.

Nahtigal, Rajko. 1961. Die slavischen Sprachen. Wiesbaden: Harrasowitz.

Nichols, Johanna. 1993. "The Linguistic Geography of the Slavic Expansion." In American Contributions to the Eleventh International Congress of Slavists, edited by R. Macguire and A. Timberlake, 377-389. Columbus: Slavica.

Olander, Thomas. 2012. "Proto-Indo-European *-os in Slavic." Russian Linguistics 36:319341.

Paul, Herman. 1880 Prinzipien der sprachgeschichte. Tübingen: Max Niemeyer.

Rešetar, M. 1898. "Primorski lekcionari Xv. vijeka." Rad 136:97-199.

Riester, Arndt and Stefan Baumann. 2013. "Focus Triggers and Focus Types from a Corpus Perspective." In Dialogue and Discourse. Special Issue "Annotating Pragmatic and Discourse Phenomena," edited by S. Dipper, H. Zinsmeister and B. Webber. Draft manuscript.

Rooth, Mats. 1992. A Theory of Focus Interpretation. Natural Language Semantics 1:75116.

Schulze, Wilhelm. 1906. "Kakophonie." Zeitschrift für vergleichende Sprachforschung 39:612.

Silverstein, M. 1976. "Hierarchy of Features and Ergativity." In Grammatical Categories in Australian Languages, edited by R.M.W. Dixon, 112-171. Canberra: Australian Institute of Aboriginal Studies. 
Sławski, Franciszek. 1946. Miejsce enklityki odmiennej w dziejach języka bułgarskiego. Cracow: Polska Akademia Umiejętności.

van Tilburg, J. 1988. "Inanimate Genitive-Accusative in Serbo-Croatian (Especially in Adnominal Relative Clauses)." Studies in Slavic and General Linguistics 11:535-620.

Vaillant, Andre. 1958. Grammaire comparée des langues slaves, Tome II. Morphologie. Deuxième partie: Flexion pronominale. Lyon: IAC.

Vaillant, Andre. 1964. Manuel du vieux slave, Vol. 1. 2nd ed. Paris: Institut d'Études Slaves.

van Wijk, Nicolaas. 1931. Geschichte der altkirchenslavischen Sprache. Berlin: Walter de Gruyter.

Vondrák, Wenzel. 1908. Vergleichende slavische Grammatik, Vol. 2. Göttingen: Vandenhoek und Ruprecht.

van Wijk, Nicolaas. 1926. "Review of St. M. Kul'bakin, Палеографска и језичка испитивања о Мирослављевом Јеванђељу.” Zeitschrift für slavische Philologie 3:259-264.

Winkler, Susanne. 1997. Focus and Secondary Predication. Berlin: Mouton de Gruyter.

Weiss, Michael. 2011. Outline of the Historical and Comparative Grammar of Latin, and printing. Ann Arbor: Beech Stave.

Yokoyama, Olga T. 1986. Discourse and Word Order. Amsterdam: John Benjamins.

Yokoyama, Olga T. 2009. "Sentence and Phrase Intonation." In Die slavischen Sprachen, edited by S. Kempgen et al., 115-128. Berlin: de Gruyter.

Zaliznjak, A.A. 2004. Drevnenovgorodoskij dialekt. 2nd ed. Moscow: Jazyki Russkoj Kul'tury.

Zaliznjak, A.A. 2008. Drevnerusskie ènklitiki. Moscow: Jazyki Slavjanskix Kul'tur. 


\section{Appendices for Further Examples}

\section{(A) Accusative Personal Pronouns after i}

$\mathrm{K}$ 32.6: iny milostijg tvoejo prïmi [sic etiam nos per gratiam tuam sustineas] "Support also us with your grace."

J. 15.20 (A, o): i vy iždengtŭ [kai humâs diốksousin] "They will also persecute you."

\section{(в) Gen.-acc. Pronouns in Contrastive Focus}

J. 15.18 (A, M, z s, o z omits vasŭ. o adds it marginally): vědite jako mene prěžde vasŭ

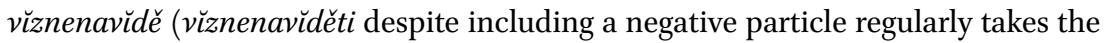
accusative). [ginốskete hóti emè prôton humôn memísēken] "ye know that it (the world) hated me before it hated you."

J. 16.27 (M, Z, O, v but A, s mę): samŭ bo otecŭ ljubitŭ vy, jako vy mene vŭzljubiste [autòs gàr ho patèr philề humâs, hóti humeîs emè pephilékate] "For the Father himself loveth you, because ye have loved me."

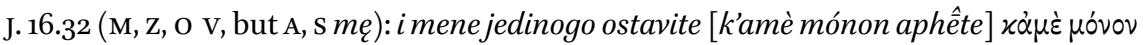
$\dot{\alpha} \varphi \hat{\eta} \tau \varepsilon$ (Behold, the hour cometh, yea, is now come, that ye shall be scattered, every man to his own) "and shall leave me alone." (But I won't be alone.)

M. 27.40 (M, Z, O, v, but A, s sę): sŭpasi sebe [sôson seautón] (Vulg. salva temetipsum) "Save thyself!"

L. $9.25(\mathrm{M}, \mathrm{Z}, \mathrm{A}, \mathrm{V}$, verse missing from s): ašte priobręštetŭ veš mirŭ, a sebe pogubitŭ [kerdếsas tòn kósmon hólon heautòn dè apolésas] "If he gain the whole world, and lose himself."

L. 16.15 (M, z, s, o, v, but A sę): vy jeste oprav̌̆dajoštei sebe prědŭ clvky. [humeîs este hoi dikaioûntes heautoùs enốpion tồn anthrốpōn] "Ye are they which justify yourselves before men." (But God knows your hearts.)

Supr. (VPauli et Iulianae 2v.11): meně bo oblı̆gǔčajetŭ otŭ mokŭ Xs. tebe že imatŭ pričęsť̆nika sŭtvoriti ognju. [emè mèn epokouphizei tôn basánōn ... Christós. sè dè ékhei klēronomềsai tò pûr] "Me Christ protects from tortures but he will make you a shareholder of fire."

Enina Ap. (Ep. Jo. 1.4.19): my ljubimyi zane onŭ prěžde vŭzljubi nasŭ [hēmeîs agapồmen hóti autòs prôtos ègápēsen hēmâs] "We love him because he first loved us."

\section{(c) Gen.-acc. as Subject of Secondary Predication}

Supr. (VCononis 24v.6) [ azǔ] tebe stara sqšta i tacěmi sědinami ukrašena sqšta [ž̌rę] (My supplement for the sake of illustration) [egò mén se presbútēn ónta kai toiaútēi poliâi kekosmèménon horôn ] "I seeing you being old and adorned with such gray hairs." Euch. Sin. 85a 22 Priimi mne zabloždǐsaago "Receive me who was lost." ga1o (c): samŭ že sebe esi stvorilŭ bez otŭvěta na sqdŭny denŭ. "You made yourself without excuse on the judgment day." 
$2 \mathrm{a} 40$ (c): dlǔženŭ jestŭ v̌sěkŭ krǔšteny samŭ sebe čista chraniti "Each Christian should keep himself pure."

$5 \mathrm{a} 4$ (c): sebe prědastŭ [heautòn ekdídōsi] "gives himself up"; $2 \mathrm{~b}_{32}$ (c): ne povinna sebe věčŭnumu ognju osqždenŭju nepǔštjuetŭ "who thinks himself not subject to condemnation to eternal fire" (but here negation may be responsible for the genitive).

(D) ocs acc. Translating Greek Stressed Accusative

J. 8.19 (M, Z, A, not in s): ašte mę biste věděli [ei emè éideite] "if ye had known me."

J. $8.42(\mathrm{M}, \mathrm{z}, \mathrm{A}$, not in s): ašte bogŭ otǐc ̌ vašı bi bylŭ, ljubili mę biste [ei ho theòs patèr humồn ền, ègapâte àn emé] "If God were your father, ye would love me."

J. 17.18 (M, A, S, not in $\mathrm{z}$ ): jakože ty mę posŭla vŭ vı̆š mirŭ [kathòs emè apésteilas eis tòn kósmon] "as thou hast sent me into the world"

J. 17.23 (M, A, s, not in z): jakože i mę vŭzljubilŭ jesi [kathòs emè ègápēsas] "as thou hast loved me"

L. 24.39 (M, A, not in S, z) jakože męvidite imošta [kathòs emè theōreîte ékhonta] "as ye see me have"

J. $12.45(\mathrm{M}, \mathrm{z}$, not in A, s): i vidęi mę viditŭ posŭlavŭšajego mę [kai ho theōrồn emè theōrê̂

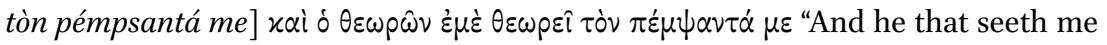
seeth him that sent me."

L. 9.48 bis (M, z, not in A, s): jǔže ašte priimetŭ otročę se vŭ imę moje mę priemljetŭ. i jǔze ašte priemletŭ mę, priemletŭ posŭlavǔšaago mę [hós eàn déksētai toûto tò paidion epi tồi onómatímou, emé dékhetai kai hós àn emè déksētai, dékhetai tòn aposteilantáme]. "Whosoever shall receive this child in my name receiveth me: and whosoever shall receive me, receiveth him that sent me."

\section{(E) Accusative kogo in the Gospels}

M. $16.15(\mathrm{M}, \mathrm{z}, \mathrm{A})$ vy že kogo mę glete byti [humeîs dè tína me légete eînai] "But whom say ye that I am?"

Mr. 8.27 (M, z, A, s) kogo mę gljqtǔ člvci byti [tína me légousin hoi ánthrōpoieînai] "Whom do men say I am?"

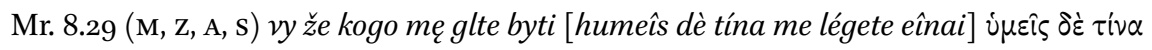
$\mu \varepsilon \lambda \varepsilon_{\gamma} \varepsilon \tau \varepsilon \varepsilon$ हival "But whom do you say I am?"

L. 9.18 (M, z) kogo mę nepǔstjujgtŭ narodi byti [tína me hoi ókhloi légousin eînai] "Whom say the people that I am?"

L. $9.20(\mathrm{M}, \mathrm{z})$ vy že kogo mę glte byti [hymeîs dè tína me légete eînai] "But whom say ye that I am?"

M 27.17 (z, M, A, S, o) kogo xoštete otŭ oboju otŭpušto vamŭ [tína thélete apolúsō humîn] "Whom will ye that I release [of both] unto you?"

M. 27.21 (M, Z, A, S, o) kogo xoštete otŭ oboju otŭpušto vamŭ [tína thélete apò tồn dúo apolúsō humîn] "Whether of the twain will ye that I release unto you?" 
Mr. $11.25(\mathrm{M}, \mathrm{z}, \mathrm{O})$ otŭpuštaite ašte čto imate na kogo [aphíete eí ti ékhete katá tinos] "Forgive, if ye have ought against any."

L 19.8 (M, Z, A, o) i ašte jesmŭ kogo čimǔ obidělŭ [kai eí tinós ti esukophántēsa] "and if I have taken any thing from any man by false accusation."

J 8.53 (M, A, o) kogo sę samŭ ty tvoriši [tína seautòn poeîs] "whom makest thou thyself?" The variant in $\mathrm{z}$ kŭto sę samŭ ty tvoriši probably does not have a trace of the old accusative but shows the nominative agreement with a reflexive pronoun which is found elsewhere in ocs and is the rule in Serbo-Croatian. Cf. the translation of Karadžić ко се ти сам градиш. 